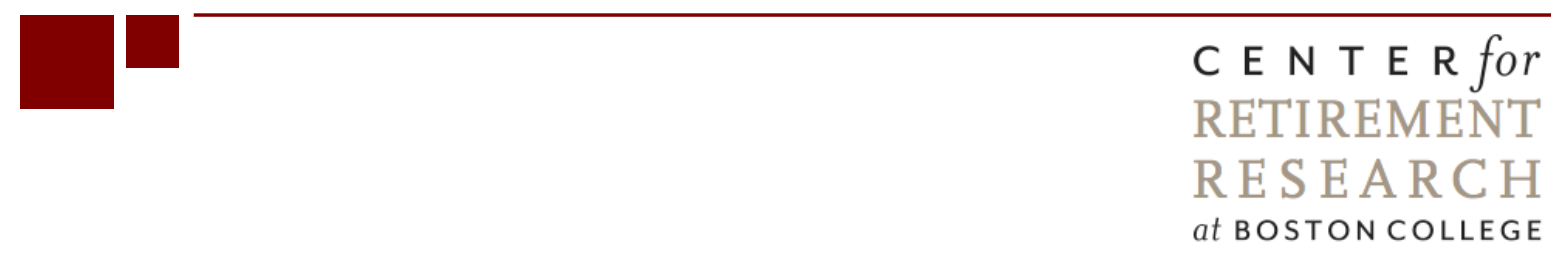

\title{
HOW BEST TO ANNUITIZE DEFINED CONTRIBUTION ASSETS?
}

\author{
Alicia H. Munnell, Gal Wettstein, and Wenliang Hou
}

CRR WP 2019-13

October 2019

Center for Retirement Research at Boston College

Hovey House

140 Commonwealth Avenue

Chestnut Hill, MA 02467

Tel: 617-552-1762 Fax: 617-552-0191

https://crr.bc.edu

All of the authors are with the Center for Retirement Research at Boston College (CRR). Alicia H. Munnell is director and the Peter F. Drucker Professor of Management Sciences at Boston College's Carroll School of Management. Gal Wettstein is a research economist. Wenliang Hou is a senior research advisor. The opinions and conclusions expressed are solely those of the authors and do not represent the views of Boston College. The authors would like to thank Robert Pozen for his generous support of this research and for insightful comments at every stage of the process; Mark Iwry for his assistance in developing the Social Security bridge option; and William Gale, Kevin Hanney, David John, Dale Kintzel, Moshe Milevsky, Olivia S. Mitchell, Richard Shea, and Mark Warshawsky for helpful comments.

(C) 2019, Alicia H. Munnell, Gal Wettstein, and Wenliang Hou. All rights reserved. Short sections of text, not to exceed two paragraphs, may be quoted without explicit permission, provided that full credit, including (C) notice, is given to the source. 


\section{Introduction}

Unlike defined benefit pensions that provide participants with steady benefits for as long as they live, 401(k) plans and Individual Retirement Accounts (IRAs) provide little guidance on how to turn accumulated assets into income. As a result, retirees have to decide how much to withdraw each year and face the risk of either spending too quickly and outliving their resources or spending too conservatively and consuming too little. Surveys of individuals' plans and several recent studies suggest that people will not draw down their accumulations for fear that they will exhaust their money and be unable to cover end-of-life health care costs. ${ }^{1}$ They also must consider how to invest their savings after retirement. These are difficult decisions.

Better strategies are possible that will ensure a higher level of lifetime income, reduce the likelihood that people will outlive their resources, and alleviate some of the anxiety associated with post-retirement investing. Workers could use a portion of their 401(k) and IRA assets to purchase an immediate annuity that pays a fixed amount throughout their lives, typically starting at age 65. Or they could purchase an advanced life deferred annuity (ALDA) that requires a smaller share of accumulated assets and begins payments at a later age like 85. Alternatively, they could use their assets to delay claiming Social Security - essentially purchasing an inflationindexed annuity. Right now, none of these three options is commonly used. Very few workers choose to purchase immediate or deferred annuities (the first two options). And few retirees appear to be deferring claiming in order to receive the maximum annuity income from Social Security - most people simply retire earlier and claim immediately.

Increasing annuitization in a meaningful way would require embedding annuities in 401(k) plans, with annuitization as the default. Recent proposed federal legislation, such as the SECURE Act (Setting Every Community Up for Retirement Enhancement), encourages plan sponsors to offer annuities in their plans by establishing a fiduciary safe harbor when specific statutory conditions are followed in selecting an insurance company. This legislation does not address, however, the question of defaults or the possibility of using 401(k) assets to purchase additional Social Security benefits. Moving forward on these fronts would require some consensus about the appropriate share of $401(\mathrm{k})$ assets to be annuitized and the best method for annuitizing them.

\footnotetext{
${ }^{1}$ For example, see Poterba, Venti, and Wise (2011) and Society of Actuaries (2017).
} 
To address these issues, this paper compares the level of lifetime utility generated by alternative annuitization approaches - immediate annuities, deferred annuities, and additional Social Security through delayed claiming. The analysis also tests different assumptions for the share of initial wealth that participants use to purchase these products.

The discussion proceeds as follows. The first section summarizes the case for annuitization and the reasons why retirement wealth is under-annuitized. The second section discusses the evidence on existing embedded annuities. The third section describes an approach to encourage participants to use some of their accumulated assets to delay claiming Social Security. The fourth section analyzes the various annuitization strategies for 1) the median household where mortality is the only source of uncertainty; 2) the median household where the model incorporates consumption shocks and stochastic investment returns; and 3) households at the $75^{\text {th }}$ and $90^{\text {th }}$ percentile of the wealth distribution when shocks and returns are incorporated. The final section concludes that once shocks are included in the analysis, the Social Security bridge option provides the best outcome for households in the middle of the wealth distribution. And a promising way to ensure that such a strategy achieves widespread adoption is by incorporating it directly into 401(k) plans as the default drawdown option. Households at the $90^{\text {th }}$ percentile of wealth would benefit from additional annuitization, such as easy access to a deferred annuity.

\section{The Case for and Resistance to Purchasing Annuities}

Annuities are contracts offered by insurance companies that provide a stream of monthly payments in exchange for a premium. The annuity not only protects people from outliving their resources but also allows more annual income than most could provide on their own. These advantages are possible because insurance companies pool the experience of a large group of

people and pay benefits to those who live longer than expected out of premiums paid by those who die early. Thus, pooling creates a "mortality credit."

The most familiar annuity is the single-life "single premium immediate annuity," which involves an individual making a one-time premium payment in exchange for annuity payments that start immediately. Annuities can cover both spouses (joint and survivor), they can guarantee payments for a certain period such as ten or twenty years, and they can provide payments based on some underlying portfolio (inflation indexed or linked to stocks). In recent years, advanced 
life deferred annuities (ALDAs) - which involve a later start date for payments - have garnered more attention because they require less investment on the part of the retiree. ${ }^{2}$

\section{The Case for Traditional Annuities}

The income gains from buying an annuity are substantial. According to the website immediateannuities.com, a 65-year old male could expect to receive $\$ 6,340$ each year from annuitizing \$100,000 (see Figure 1). This amount not only lasts for as long as the individual lives but also exceeds what he could generate on his own under an array of alternatives. Consider self-annuitization (Option 1) where the retiree invests $\$ 100,000$ in an asset with the same 3-percent nominal return assumed by commercial insurers and withdraws $\$ 6,340$ each year. ${ }^{3}$ This option works well for a period of time, but the assets are depleted after 20 years (at age 85), when the retiree still has a 44-percent chance of being alive. Option 2 could be a longlife strategy where the retiree selects some distant age such as 100 and spends down assets evenly over this period. The problem here is that the retiree would be able to spend only $\$ 4,450$ each year over the 35-year period and would have no resources to support himself should he live beyond 100. Option 3 could be a strategy based on life expectancy where the retiree spends a fraction of assets each year based on expected remaining years of life. Income under this option is always lower than that provided by an annuity, and the withdrawals rise and then fall with age, creating a significant chance of impoverishment in very old age. Option 4 could rely on the IRS's required minimum distribution (RMD) rules as a drawdown strategy. This option avoids running out of money but still provides income well below that available from the purchase of an annuity. In terms of providing longevity security and producing income, the immediate annuity appears to dominate other drawdown strategies.

\footnotetext{
${ }^{2}$ In general, annuities - particularly ALDAs - are not indexed to inflation.

${ }^{3}$ The 3-percent assumed return is based on the yield on AAA corporate bonds with 20-year maturities in August 2019.
} 
Figure 1. Income Produced from $\$ 100,000$ by Drawdown Strategy

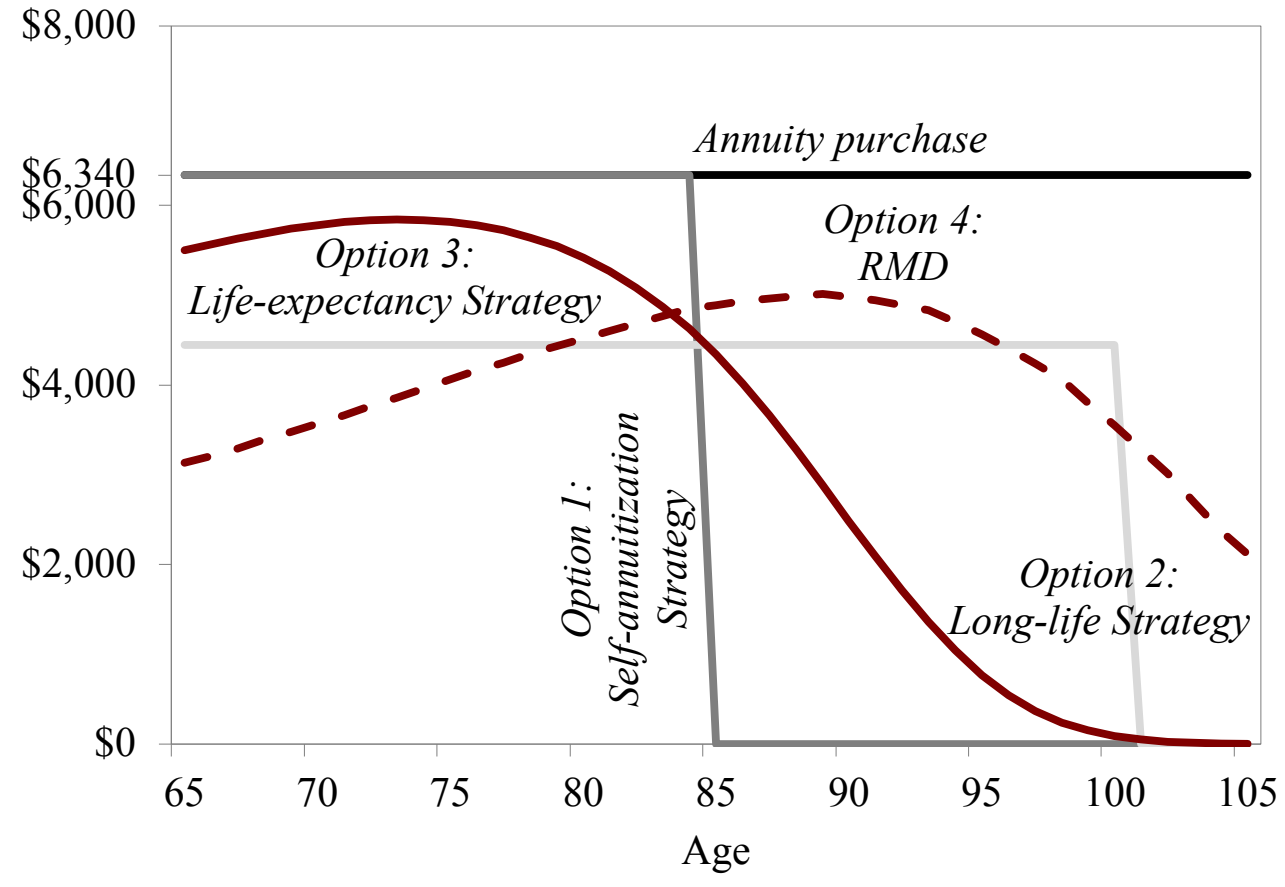

Notes: The annuity amount is from a quote as of 7/1/19 for a 65-year old male in Massachusetts. The other calculations assume a 3-percent nominal annual return, based on the yield on AAA corporate bonds with 20-year maturities in August 2019.

Sources: The website "immediateannuities.com;" and authors' calculations.

For these reasons, economic theory suggests that people would be interested in buying annuities. ${ }^{4}$ Rational life-cycle consumers with no interest in leaving a bequest would always choose to annuitize 100 percent of their wealth. ${ }^{5}$ After all, they face a choice between a traditional investment with a market return and an annuity with a market return plus a mortality credit. The only cost to consumers is that the annuity payments stop at death. But if they place no value on wealth after death - that is, they have no bequest motive - the cost of the annuity is zero.

Researchers have attempted to calculate the value to individuals of access to an annuity market. The concept they use is annuity equivalent wealth. ${ }^{6}$ Calculating this number involves comparing levels of well-being with and without an annuity. The experiments start with the

\footnotetext{
${ }^{4}$ Modigliani (1986).

${ }^{5}$ Yaari (1965). Davidoff, Brown, and Diamond (2005) show that the 100-percent annuitization strategy also depends on "complete markets," that is, people must be able to insure themselves against all major contingencies, including the need for long-term care.

${ }^{6}$ Brown, Mitchell, and Poterba (2001), Brown and Poterba (2000), Brown (1999).
} 
assumption that an individual has $\$ 100,000$ of annuitized wealth and then ask how much additional wealth an individual would need to be as well off without annuities as with them. The answer depends on many factors - such as attitudes toward risk, access to other sources of annuitized income, and marital status - but is typically greater than $\$ 100,000$.

Despite the enormous potential gains from annuitization, the market for immediate annuities in the United States is miniscule. In 2018, sales of single premium immediate annuities amounted to only $\$ 9.7$ billion. $^{7}$ In comparison, total long-term care expenditures for the elderly amounted to roughly $\$ 150$ billion. $^{8}$

\section{Reasons for Not Buying an Annuity}

Researchers have done a lot of work to find out why people do not buy annuities, and the reasons fall into three categories: costs and risks of annuities, financial realities, and irrational resistance.

Costs and Risks of Annuities. Annuities are expensive for the average person. The high costs come from three sources. The first is adverse selection. ${ }^{9}$ Annuities are most attractive to people who are likely to live for a long time; those with a serious illness keep their cash. (One study found that annuitants live, on average, about 3.5 years longer than the rest of the population.) ${ }^{10}$ To address the adverse selection problem, private insurers raise premiums, which makes annuities expensive for a person with average life expectancy. The second source of the high price is the insurance company's need to cover administrative and marketing costs and to make a profit. Third, insurers must maintain capital reserves to cover adverse experience, and this requirement involves an opportunity cost in terms of foregone returns. ${ }^{11}$

Researchers have measured the impact of adverse selection and administrative and marketing costs on the price of annuities by calculating money's worth ratios for these products. $^{12}$ Early calculations showed that these two factors reduced the ratio of the present

\footnotetext{
${ }^{7}$ LIMRA (2019). In fact, even this number overstates the sale of life annuities because it includes products that are period certain only and have no life-contingent payments (Brown and Poterba 2000). This number does not include $\$ 75$ billion of variable annuity sales, as these products are generally investment vehicles rather than lifetime income guarantees.

8 Authors' estimates based on data from the Centers for Medicare and Medicaid Services (2017).

${ }^{9}$ See, for example, McCarthy and Mitchell (2002).

${ }^{10}$ Brown et al. (2001).

${ }^{11}$ Looking at the United Kingdom, Finkelstein and Poterba $(2002,2004)$ found that the lack of actuarially fair prices contributed to the low take-up of annuities.

12 Mitchell et al. (1999), Brown, Mitchell, and Poterba (2002).
} 
discounted value of benefits relative to price by about 15-20 percent (Mitchell et al. 1999). These researchers, as well as Brown (2009), conclude, however, that adverse selection and fees are not enough to explain the reluctance to buy annuities. And Davidoff, Brown, and Diamond (2005) contend that even with incomplete annuity markets most consumers will want to annuitize a substantial portion of their wealth. In fact, Peijnenberg, Nijman, and Werker (2016) find that full annuitization remains optimal if individuals are allowed to save out of annuity income and invest in equities. ${ }^{13}$

Financial Realities. Another important factor that may explain part of the reluctance to annuitize is the presence of preexisting annuitized wealth. People already have a lot of their retirement wealth annuitized through Social Security, which is most people's largest asset as they enter retirement. ${ }^{14}$ Homeownership and Medicare subsidies also provide a form of annuitized wealth. The more preexisting annuitized wealth that households hold, the less they will gain from additional annuitization. ${ }^{15}$

In addition, families provide a certain amount of self-insurance. ${ }^{16}$ Spouses generally pool their resources while both are alive and name each other as the major beneficiary in the case of death. If one spouse lives to be very old, the probability is high that the other spouse has already died and left a bequest to help finance consumption. In effect, the potential death of each spouse hedges the risk of the surviving spouse outliving his or her resources. As a result, the two can set a level of consumption that takes account of the expected bequest. Simulations suggest that marriage provides 46 percent of the protection offered by a fair annuity for a 55 -year-old individual. ${ }^{17}$ Adding risk sharing between parents and children, the risk-sharing potential within families is substantial.

Another obvious - and also family-related - reason that people might be reluctant to annuitize is their desire to leave a bequest to their heirs. ${ }^{18}$ Since individuals without a bequest motive place no value on any wealth that they hold at death, it would be irrational for them not to select the higher guaranteed income that annuities provide. ${ }^{19}$ But individuals with a bequest

\footnotetext{
${ }^{13}$ Most research to date does not allow for exposure to equities in retirement except through variable annuities.

${ }^{14}$ Wolff (2018).

15 Bernheim (1991), Brown, Mitchell, and Poterba (2001), Benitez-Silva (2003), and Milevsky and Young (2007) show that households with higher annuity income relative to retirement assets are less likely to annuitize.

${ }^{16}$ Kotlikoff and Spivak (1981), Brown and Poterba (2000).

${ }^{17}$ Kotlikoff and Spivak (1981).

${ }^{18}$ Friedman and Warshawsky (1990) and Lockwood (2012).

19 Yaari (1965).
} 
motive do value the wealth left behind and, therefore, will not want to annuitize all their assets. While early research found mixed results on the importance of a bequest motive, a recent paper by Lockwood (2018) suggests that the bequest motive may be more important than previously thought. ${ }^{20}$

A final rational reason why people may be reluctant to annuitize is that they are worried about large unanticipated expenses, especially those related to their health. ${ }^{21}$ The cost of regular illness is not a particularly serious problem. Most people ages 65 and older have Medicare coverage for both doctor visits and hospital stays. Although Medicare requires deductibles and copayments, the vast majority of beneficiaries are protected by supplemental insurance. ${ }^{22}$ The real problem is long-term care. ${ }^{23}$ Medicare does not cover extended nursing home care, and most people do not have long-term care insurance. ${ }^{24}$ Medicaid will cover nursing home costs for low-income individuals, but only once they have fully exhausted their assets. Furthermore, if mortality is correlated with large uninsured medical and long-term care expenses, annuities become even less attractive as their present value falls at the same time as the need for large expenditures rises (Reichling and Smetters 2015).

Irrational Resistance. Non-rational factors may also help explain the small size of the immediate annuity market - specifically a preference to retain and control wealth and a lack of understanding of the advantages that annuities offer. ${ }^{25}$ Interestingly, people appear to be generally satisfied when they do receive retirement benefits in the form of annuities. Few people complain about their benefits from Social Security, demanding that they be paid as a lump sum. On the other hand, people who start with a pile of assets rarely exchange it for a stream of income. The behavioral economics literature is full of experiments showing that once people have something, they are reluctant to give it up (see, for example, Benartzi, Previtero, and Thaler

\footnotetext{
${ }^{20}$ For a summary of the literature as of 2003, see Munnell and Sundén (2003). Lockwood (2018) contends that individuals' insurance and savings choices are inconsistent with standard lifecycle models without bequests. In an earlier paper (2012), Lockwood finds that the presence of bequest motives can largely explain the failure of individuals to annuitize any of their wealth given the prevailing market annuity prices.

${ }^{21}$ See Ameriks et al. (2011) and De Nardi, French, and Jones (2010).

${ }^{22}$ Multack and Noel-Miller (2014).

${ }^{23}$ Brown and Finkelstein (2011). Interestingly, some annuity products have been proposed that would integrate long-term care insurance and lifetime income guarantees in a way that might ameliorate the gaps in the two separate markets (for example, see Brown and Warshawsky 2013).

${ }^{24}$ Medicare does cover up to 100 days of skilled nursing care after a hospital stay. It is available only to those requiring medical care, as opposed to assistance solely with routine daily activities.

${ }^{25}$ For example, see Brown et al. (2008), Sagara et al. (2011), and Brown et al. (2017).
} 
2011). Since annuity contracts are largely irreversible, individuals balk at handing over control of their life savings to an insurance company.

Moreover, people generally prefer lump-sums to flows. The real world and the psychological literature are full of such examples. Employers exploit this preference by offering prospective employees immediate signing bonuses, and the great majority of taxpayers overpay their income taxes to ensure themselves a lump-sum refund. ${ }^{26}$ Furthermore, Brown (2009) hypothesizes that holding wealth, instead of receiving income, may give people the illusion of control over their financial future.

In addition to having rational and non-rational preferences for lump sums, most people also fail to understand or appreciate the benefits of annuitization. A common misunderstanding focuses on the risk of dying early and receiving less than a person pays in. ${ }^{27}$ One piece of evidence supporting the fear of dying too soon is a strong preference for annuities that guarantee payments for a fixed period of time, with these payments going to the purchaser's spouse (or other designated beneficiary) if the purchaser should die early. This investment framing, however, ignores the primary rationale of annuitization: providing a vehicle for sustaining consumption by insuring against the possibility of living longer than expected. Agnew et al. (2008) and Benartzi, Previtero, and Thaler (2011) both found that a consumption rather than an investment framing makes people much more willing to consider annuities.

Combine all these considerations with concerns about the viability of insurance companies in the wake of the 2008 financial crisis, and it seems unlikely that many people will be willing to hand over $\$ 100,000$ to an insurance company for a traditional annuity. ${ }^{28}$ Hence,

\footnotetext{
${ }^{26}$ Why do people prefer lump sums? An immediate lump sum allows for big-ticket purchases, such as paying off a mortgage or taking a vacation, which are not possible with small annuity payments. This preference for lump sums, however, more likely reflects a high discount rate - that is, people simply do not put much value on money they will get in the future. For example, one researcher found that the median respondent would give up $\$ 3,000$ today in exchange for a payment ten years in the future only if the delayed payment was at least $\$ 10,000$ (Thaler 1994). This response implies a discount rate (continuously compounded) of 12 percent. (As inflation was, at the time of the study, running about 3 percent, the real discount rate would be about 9 percent.)

${ }^{27}$ Brown and Warshawsky (2004), Brown et al. (2008).

${ }^{28}$ This concern persists despite the fact that life insurers rarely go out of business (less than 0.5 percent of large life insurers went bankrupt per year over the last two decades, National Organization of Life \& Health Insurance Guaranty Associations 1992-2015), and their commitments are guaranteed by the state in cases of insolvency.
} 
retirement experts have turned their attention to the ALDA, sometimes called longevity insurance. $^{29}$

\section{Advanced Life Deferred Annuities}

Milevsky (2005) proposed an advanced life deferred annuity that he thought might better meet the needs of retirees. The original notion was that people would pay premiums over their worklife that would produce a stream of income at, say, age 85. Most of the conversation these days assumes a single lump-sum premium payment once the person retires.

The key advantage of an ALDA is that participants can buy longevity insurance by spending only a fraction of the cost of an immediate annuity. For example, the typical description goes something as follows. An individual with $\$ 100,000$ at age 65 could purchase an immediate annuity and receive an income stream of $\$ 6,340$, or could purchase $\$ 6,340$ beginning at 85 for $\$ 16,000$. While the statement is true, the two strategies do not provide the same outcome. The individual purchasing the ALDA has only $\$ 84,000$, not $\$ 100,000$, to spend between 65 and 85 , producing an income stream of $\$ 5,325$ over the period before the ALDA kicks in at 85 . Alternatively, to produce a flat nominal income stream, the individual could invest less in the ALDA and raise withdrawals between 65 and 85, yielding an annual income of $\$ 5,740$. This amount is substantially less than the $\$ 6,340$ produced by an immediate annuity because the individual benefits less from the mortality credits described above.

The potential advantages of the ALDA are threefold. First, it provides "longevity insurance" so that the individual will not run out of money. Second, it leaves the purchaser with $\$ 84,000$ to spend between ages 65 and 85 . And third, it makes the spending of the $\$ 84,000$ much simpler, because the individual knows that the ALDA will kick in at 85 . The downside is that the individual ends up with less lifetime income than possible through the purchase of an immediate annuity.

Even though the ALDA appears to have many appealing properties, it is a new product and regulatory barriers and sponsor concerns have impeded its adoption. To encourage the use

\footnotetext{
${ }^{29}$ Technically, since 2014, the only form of ALDA that 401(k)s or IRAs can provide (as a practical matter) is the Qualified Longevity Annuity Contract. For the Treasury rules governing QLACs, see U.S. Department of the Treasury (2014a).
} 
of ALDAs, the Treasury in 2014 removed some of the constraints..$^{30}$ The new regulations clarified that participants did not face an "all or nothing" choice at retirement, but could split their assets - using a portion to purchase an annuity and taking the rest as a lump sum. Most importantly, these regulations made it possible for the first time to have ALDAs in 401(k)s and IRAs and created the Qualified Longevity Annuity Contract (QLAC), under which individuals could contribute 25 percent of their assets (up to $\$ 125,000$ ) with those assets exempt from the RMD. ${ }^{31}$ In the example above, if an individual had an account balance of $\$ 100,000$ and invested $\$ 16,000$ in an ALDA, only $\$ 84,000$ would be subject to the RMD rules.

As noted in the introduction, the SECURE Act, which is winding its way through Congress, further encourages employers to offer annuities in their plans by establishing a fiduciary safe harbor for defined contribution plan sponsors that use reasonable procedures for selecting their insurance company. These changes would all help make it easier to offer annuities and particularly facilitate the provision of ALDAs. But the low level of sales suggest that people are never going to buy these products without prodding. One way to get people to use these products more frequently is to embed them in 401(k)s and other defined contribution plans and to make them the default, an approach expressly permitted by additional Treasury guidance in 2014. ${ }^{32}$

\section{Existing Embedded Annuities}

The rational arguments laid out above clearly indicate that annuitization may not be for everyone - e.g., those who have not saved very much already have most of their income as an annuity through Social Security and need to have some liquid assets in case of an emergency. But a case can be made that those with non-trivial 401(k) balances might be open to annuitizing at least part of their assets if the process were simple and transparent and did not require them to seek out annuities on their own in the market.

In some cases, defined benefit plans require participants to make an active choice between a lifetime income option and a lump sum. This situation has offered researchers an opportunity to investigate the take-up of annuities when the choice is easy. The results show that

\footnotetext{
${ }^{30}$ Canada has also recently moved to permit allocating some defined-contribution-type savings to ALDAs.

${ }^{31}$ U.S. Department of the Treasury (2014a).

${ }^{32}$ U.S. Department of the Treasury $(2014 b)$.
} 
when an annuity is readily available, many defined benefit plan participants with a nontrivial amount of pension assets choose an annuity over the lump-sum option (see Table 1). These results from defined benefit plans suggest that embedding annuities in defined contribution plans could potentially increase annuitization as well.

Table 1. Percentage of Retirees with a Defined Benefit Plan Annuitizing When Offered a Lump Sum

\begin{tabular}{lc}
\hline Study & Retirees annuitizing \\
\hline Hurd and Panis (2006) & $61 \%$ \\
Bütler and Teppa (2007) & 86 \\
Mottola and Utkus (2007) & 27 \\
Benartzi, Previtero, and Thaler (2011) (IBM employees) & 88 \\
Benartzi, Previtero, and Thaler (2011) & 53 \\
\hline
\end{tabular}

Source: Benartzi, Previtero, and Thaler (2011).

While annuitization appears to be a good option for most people and is potentially attractive if offered through a 401(k) plan, very few such opportunities currently exist. In 2016, only 10 percent of employer-sponsored plans offered any in-plan lifetime income products, according to a survey by the Plan Sponsor Council of America. ${ }^{33}$ And, among plans managed by Vanguard, only 7 percent of participants were offered an embedded annuity in 2018. ${ }^{34}$

To the best of our knowledge, only three instances exist of annuities embedded in defined contribution plans: United Technologies Corporation's Lifetime Income Strategy; TIAA's Traditional Annuity; and the Guaranteed Lifetime Withdrawal Benefit product, which financial services firms offer employers for inclusion as an option in their 401(k) plans.

\section{United Technologies Corporation (UTC)}

UTC is the only Fortune 100 U.S. company that offers its workers the ability to convert their 401(k) into a guaranteed income stream as a default option. This option - the Lifetime Income Strategy (LIS) - is intended to make the defined contribution plan function more like a defined benefit plan. The LIS design aims to keep costs low, offer flexibility in the payout phase, and provide adequate retirement income. UTC viewed this approach as the best

\footnotetext{
${ }^{33}$ Plan Sponsor Council of America (2018).

${ }^{34}$ Vanguard (2019).
} 
compromise between an immediate fixed annuity, which would have provided the highest level of income, and a systematic-withdrawal plan, which would have ensured the greatest level of liquidity.

UTC auto-enrolls new hires into a default investment option that includes the LIS. Before age 48 , this default is simply a target date fund with a mix of stocks and bonds. The default contribution rate is 6 percent, with auto-escalation of 1 percent per year up to a cap of 10 percent. Employees receive a 3.6-percent employer contribution. Starting at age 48, the default begins to move a participant's assets to a secure income portfolio - the LIS component. The initial transfer is about 4 percent of assets, but this proportion gradually increases until age 60, when the participant's entire 401(k) account balance is allocated to the LIS portfolio. ${ }^{35}$

To handle the LIS benefit guarantee, UTC contracts with insurance companies. Insurers are invited each year to bid on the amount that they could provide in annual income out of that year's contributions to the LIS. Once the bids are accepted, the guaranteed income amount from the year's contributions is locked in. This process is repeated each year. The insurer fees are about 7 basis points for those age 48, rising to about 100 basis points by ages 60 and over. ${ }^{36}$ With respect to maintaining or consolidating participant assets, the UTC plan allows separated employees to keep their assets in the plan and all participants can transfer defined contribution assets accumulated from other employers into their UTC account.

Beginning at age 60 , retiring participants enter the payout phase. The assets in a participant's account are used to pay out the "income benefit." If the account balance is exhausted, then the insurance company takes over and continues to pay out the income benefit. The payout arrangement is much more flexible than that associated with a fixed annuity. First, retirees have the option of withdrawing more than the "income benefit" to cover large purchases or to meet an emergency, and these "excess withdrawals" reduce their future benefits. Second, LIS participants can designate a beneficiary in the event that they die before their assets run out. Third, plan participants can terminate the annuity at any time, converting their stream of income into a lump sum, with no surrender charge.

\footnotetext{
${ }^{35}$ Existing employees who are not in the LIS tier can convert all their plan assets into guaranteed annuities at retirement, for a fee. Those under age 60 who were in the default investment allocation at the time the LIS was introduced were similarly defaulted into the LIS.

36 The fund also has standard fees for investment management and administration, which range from about 14 basis points to 24 basis points.
} 
At the end of July 2019, the company's defined contribution plan had over 140,000 participants and $\$ 28.5$ billion in assets. The LIS, which was introduced as the default for new hires in 2012, had about 45,000 participants and \$1.9 billion in assets. ${ }^{37}$ Kevin Hanney, UTC's Senior Director of Pension Investments, estimates that about one third of employees who were ever enrolled in the LIS have chosen to opt out. (This figure does not include those who opted out before they were enrolled.)

\section{TIAA Traditional Annuity}

Some other employers also offer embedded annuity options, perhaps most prominently through the TIAA Traditional Annuity, although the annuity is not the default. This product is widely available to over 5 million workers in the non-profit sector, particularly those at colleges and universities. ${ }^{38}$ The share of TIAA Traditional Annuity participants opting for an annuity, as opposed to other payout options such as RMDs, has seen persistent declines over the past few decades. Before 1989, annuitization for TIAA participants was mandatory. Starting in 1989, TIAA began to offer non-annuity options, and the share of TIAA clients opting for an annuity has been falling since then - to 39 percent in 2012. ${ }^{39}$ This reduced share of annuitants is nevertheless still far above the share in the for-profit sector (about 10 percent). ${ }^{40}$

Workers investing in the TIAA annuity receive a guaranteed interest rate of 3 percent during the accumulation phase plus some upside potential, with the option of turning these accumulations into an annuity at retirement. The underlying investment portfolio is determined by TIAA, and typically does permit the plan to offer notional returns in excess of the guaranteed minimum; through 2012, crediting rates have exceeded 3 percent for over 40 years. $^{41}$

At retirement, individuals can convert some or all of their accumulated assets to lifetime income options, which include life only, joint survivor, or life with a guaranteed period that ensures payments continue to beneficiaries after death. ${ }^{42}$ Currently, the annuity quotes are based on a 2.5-percent interest rate and fixed mortality tables that depend on the option chosen.

\footnotetext{
${ }^{37}$ Murphy et al. (2018).

${ }^{38}$ TIAA Institute (2019).

${ }^{39}$ Ameriks (2002) and Goodman and Richardson (2014).

40 Johnson, Burman, and Kobes (2004).

${ }^{41}$ Goodman and Richardson (2014).

42 Ameriks (2002).
} 


\section{Guaranteed Lifetime Withdrawal Benefit (GLWB)}

A GLWB, a form of variable annuity, is the final type of guaranteed income that is offered to employers for inclusion as an embedded option in their 401(k) plan. ${ }^{43}$ Employers that choose to offer a GLWB to their employees as a distribution option could potentially make it a default, but this design is uncommon. ${ }^{44}$

A GLWB offers participants a chance to withdraw a fixed percentage of their "benefit base" when they purchase the product. This amount is often around 5 percent if purchased at age 65 for an individual and 4.5 percent if the guarantee applies to the spouse as well. ${ }^{45}$ Balances are generally invested in target date funds appropriate to the age of the participant. The benefit base can then increase if investment returns justify it, but it cannot decrease. The participant is charged between 50 and 100 basis points for this guarantee. Examples of such plans include IncomeFlex (offered by Prudential); SecurePath for Life (a collaboration between Diversified Investment Advisors, Transamerica and Vanguard); and SecureFoundation (offered by GreatWest).

\section{"Buying" Annuity Income from Social Security}

Given the reluctance of participants to purchase annuities on their own and the limited offerings within $401(\mathrm{k})$ plans, clearly a need exists for more ways to use plan assets to obtain annuity income. While most discussions focus on conventional products such as immediate annuities or, more recently, on qualifying ALDAs, delaying Social Security claiming is another way for participants to increase their annuity income.

Currently, most workers claim Social Security benefits before age 70 (see Figure 2) and as a result receive reduced amounts. The reduction occurs because Social Security monthly benefits are actuarially adjusted to ensure that the expected lifetime benefits for the average worker are equal whether he claims at age 62 or 70 . As a result, monthly benefits claimed at 70 are at least 76 percent higher than those claimed at 62. Thus, one option is to use a portion of

\footnotetext{
${ }^{43}$ For an analysis of this type of product, see Horneff et al. (2015) and Steinorth and Mitchell (2015).

${ }^{44}$ One proposal envisioning a default payout for retirement account balances is explored by John et al. (2019).

${ }^{45}$ See Society of Actuaries and LIMRA (2018).
} 
defined contribution wealth to "buy" more annuity income from Social Security by delaying claiming. ${ }^{46}$

Figure 2. Percentage Distribution of Social Security Claiming Age, 2017

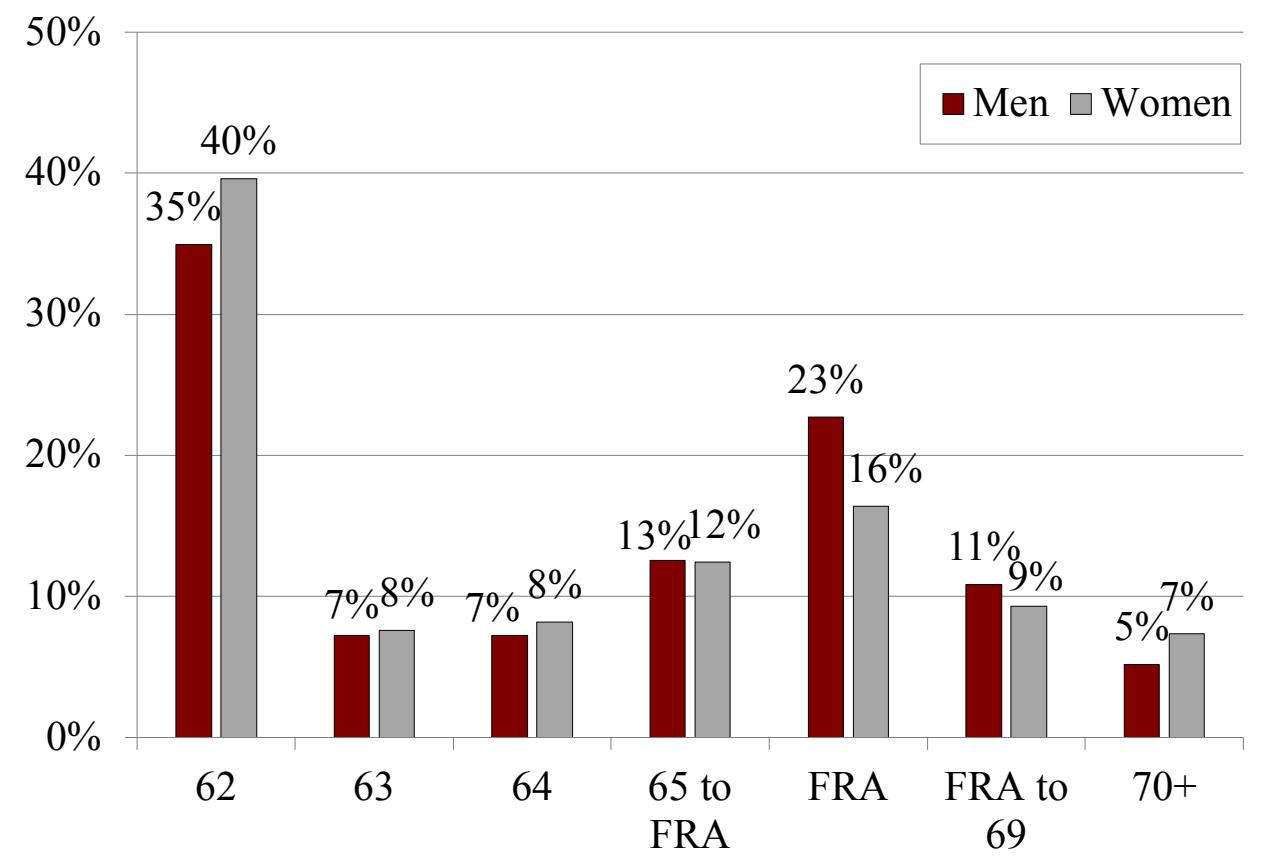

Note: Disability conversions are excluded from totals.

Source: Authors' calculations from U.S. Social Security Administration (2018).

"Buying" more annuity income from Social Security is generally more attractive than buying a commercial annuity. First, the Social Security annuity is not subject to the insolvency concerns that apply to commercial annuities, which have been a major obstacle to their inclusion in defined contribution plans. ${ }^{47}$ Second, Social Security benefits are indexed for inflation. Third, the price of Social Security is approximately actuarially fair for the average person, since benefit adjustments are based on the life expectancy of the "average" individual rather than on the above-average life expectancy of those who typically buy commercial annuities. Moreover, Social Security does not require profits or compensation for marketing, management, and risk-

\footnotetext{
${ }^{46}$ Of course, an even more straightforward approach would be to simply work longer and delay Social Security claiming in that way (as recommended, for example, in Munnell and Sass 2009). The proposal envisioned here aims to delay claiming without impacting other life decisions, such as labor supply.

${ }^{47}$ While Social Security cannot become insolvent, benefits are liable to be reduced if revenues to the program do not keep pace with its obligations. This situation is projected to arise in 2034 (U.S. Social Security Administration 2019b). Nevertheless, it seems unlikely that benefits will be reduced for current or near future beneficiaries.
} 
bearing costs. Finally, while buying an annuity from Social Security is a generally attractive option, it is especially attractive when low interest rates make it much harder for many people to live on returns from accumulated defined contribution assets.

The idea of using accumulated assets to delay claiming Social Security is not new. A number of policy experts have suggested this approach. For example, Koenig, Fichtner, and Gale (2018) proposed a new type of mandatory savings account that workers would be required to use up before receiving Social Security retirement benefits. Vernon (2018) also advocated using a portion of savings to enable delaying Social Security benefits for as long as possible. Mark Iwry of the Brookings Institution has suggested that 401(k) plans could offer a "Social Security bridge option," inspired by a similar distribution option traditionally provided by some defined benefit pension plans. ${ }^{48}$ However, we are not aware that any $401(\mathrm{k})$ plans are explicitly offering a formalized way to defer Social Security to buy more annuity income, and even if such an option were available few individuals are likely to choose it on their own.

The proposal considered here would introduce a default into 401(k) plans that would use 401(k) assets to pay retiring individuals ages 60-69 an amount equal to their Social Security Primary Insurance Amount (PIA) - the monthly amount an individual would receive from Social Security if he claimed at his full retirement age. ${ }^{49}$ The expectation is that providing a temporary stream of income to replace an individual's Social Security benefit would break the link between retiring and claiming, which is reflected in the common tendency to begin Social Security benefits upon cessation of work or to stop working when, or soon after, one can begin claiming. Breaking this link is important because the evidence indicates that most households would gain from delaying claiming their Social Security benefit. ${ }^{50}$

An advantage of this approach is that it does not require any new legislation, as it neatly fits into the existing Social Security system. Similarly, the approach does not require any new formal bureaucratic structure, nor does it involve contracting with an insurer. Finally, since this

\footnotetext{
${ }^{48}$ Iwry has advocated this idea in presentations to conferences while serving at the U.S Department of the Treasury and most recently at an April 18, 2019 Brookings Institution conference on lifetime income and a 2018 meeting of the ERISA Advisory Council.

${ }^{49}$ The proposal uses 60 as the starting age. Most employees leaving an employer at or after this age are retiring and early payments could get them in the habit of living without claiming their Social Security benefits. The concern, of course, is that essentially making Social Security available at 60 would encourage some people to retire earlier than they would have otherwise.

${ }^{50}$ See, for example, Shoven and Slavov (2014).
} 
approach does not formally include buying an annuity, it may sidestep the resistance that annuity products have garnered among the public.

Experts suggest that frontloading payments from $401(\mathrm{k})$ plans would be relatively uncontroversial if the strategy were introduced as a regular option rather than a default. ${ }^{51}$ As noted, a Social Security bridge option already exists in some defined benefit plans, whereby workers who retire before being eligible for Social Security can increase their defined benefit payments in their early years in exchange for reduced payments once Social Security kicks in. Both the bridge option under defined benefit plans and the proposed bridge option for $401(\mathrm{k}) \mathrm{s}$ use income from an individual's retirement plan to break the link between the cessation of work and the claiming of Social Security benefits.

Even with an option that is not a default, employers might worry that offering Social Security bridge payments would be seen as giving advice that participants should claim later. To help manage that risk, the option might be structured with links to educational materials from authoritative websites that show that the majority of workers would gain from postponing claiming, alongside materials explaining the downside of delayed claiming (e.g., for those with high mortality risk or in certain income tax situations). ${ }^{52}$

With this approach, it would be simple for the sponsor to amend the Summary Plan Description and perhaps provide a separate disclosure shortly before the participant reaches age 60. Even a voluntary Social Security bridge option could have an impact on claiming, because it would stand out among the current limited lump-sum withdrawal options. That is, even for workers who did not choose the option, simply drawing their attention to the possibility of separating their retirement and claiming decisions might be helpful.

Our preferred proposal, however, is to have the Social Security bridge be the default option. That is, all retiring workers 60 and older would automatically receive a payment equal to their PIA when they left the company. As with any default, the worker would retain the ability to opt out in favor of a lump-sum or other withdrawal, including leaving the funds in the plan. Even if the payments had started, workers would still be entitled to change their mind and change the size of the distribution, or switch to a lump sum for their remaining $401(\mathrm{k})$ balances, rolling the lump sum to an IRA as a tax-free transaction. Most employers would almost certainly

\footnotetext{
${ }^{51}$ Conversation and email exchanges with Mark Iwry.

${ }^{52}$ In general, the analysis presented here considers only pre-tax distributions.
} 
want additional comfort from regulators, such as an advisory opinion from the Department of Labor, that they are not giving advice and that the default is permissible. ${ }^{53}$ Receiving such approval would also help to codify the details of the strategy, providing a blueprint for plan sponsors. $^{54}$

For the plan sponsor, the mechanics would be simple. The sponsor would calculate an individual's PIA based on his employment history at the firm and some assumed wage growth. Once the payments begin, the estimated PIA could be made more precise if the worker shared his Social Security Statement. ${ }^{55}$ The payments would be made directly from the employee's 401(k) assets, where the funds would most likely be invested in a target date fund. (Some thought was given to segregating out the funds for the PIA payments and investing them in a safe asset, but the complexity of the process appears to outweigh any gains in security. Similarly, having the payments made directly by the plan instead of buying a product from an insurance company would keep costs to a minimum.) When the portion of $401(\mathrm{k})$ assets designated for this program is exhausted, the payouts would stop. Along the way, employees would receive periodic reminders from the plan that they could use these payments to delay claiming their Social Security benefit, and a reminder before the payments stop that they need to contact the Social Security Administration when they wish to claim.

The proposal is modest in scope. First, the PIA amount would be based on the worker's final earnings and some assumption about earnings growth. While getting a more complete wage history would be ideal, for workers covered by a retirement plan their final earnings would probably provide a useful estimate. ${ }^{56}$ Second, the default would apply only to the assets in the current employer's 401(k), and many workers have several 401(k)s. Eventually it might be possible to consolidate most, if not all, of an individual's defined contribution assets in one

\footnotetext{
${ }^{53}$ A question arises as to whether the default annuity option, if not included as an investment option during the accumulation phase, could be viewed as only a payout option, in which case it would be exempt from fiduciary analysis and therefore not technically required to be in the best interest of participants.

${ }^{54}$ The importance of receiving regulatory approval was stressed by several experts interviewed for this paper, including Kevin Hanney of UTC, Mark Iwry of the Brookings Institution, and David John of AARP.

${ }_{55}$ One potential way would involve combining an individual's 401(k) statement with his Social Security Statement (see Gale, John, and Smith 2012).

${ }^{56}$ This approach is in the same spirit as existing Social Security bridge options in defined benefit plans, which typically aim to provide a smooth stream of consumption to those retiring before their Social Security early or full retirement age by increasing the defined benefit payout in the first few years of retirement and decreasing it once Social Security benefits are claimed. Such plans typically approximate the Social Security benefit that employees will enjoy (see Treasury Regulation (26 C.F.R.) § 1.411(d)-3(g)(16) and Treasury Regulation (26 C.F.R.) $\S$ 1.411(a)-7(c)(4)(ii)).
} 
account and apply the default to all $401(\mathrm{k})$ holdings. ${ }^{57}$ Third, about 60 percent of retirement account money is held in IRAs, not 401(k)s. The hope is that, if the bridge option is successful in the 401(k) space, it could eventually be applied - perhaps on a voluntary basis - to IRAs.

Despite the proposal's limitations, using a portion of defined contribution wealth to delay claiming Social Security has the potential to significantly improve retirement security. In 2017, the median claiming age was 64 for men and 63 for women. For each year that an individual delays claiming, his monthly Social Security benefit increases by 7 to 8 percent up to age 70 . Therefore, this proposal could increase monthly Social Security benefits by over 50 percent for the typical retirement worker who has the resources to delay to 70.58

\section{How Do the Annuitization Options Stack Up?}

To evaluate how the various approaches - immediate annuities, deferred annuities, and the Social Security bridge - compare, the analysis assesses each one in terms of "utility equivalent wealth." This measure compares the amount of wealth that would be required to achieve the same utility under one strategy relative to another. A number less than 1 indicates that a strategy is better than the benchmark strategy of no annuitization - i.e., it requires less wealth to achieve the same utility - and a number greater than 1 indicates that it is worse.

The payouts for the annuity options are from immediateannuities.com, and reference the quotes for a 65-year-old from Massachusetts purchasing an annuity commencing on September 1, 2019. For both immediate and deferred annuities, the quotes for men and women are averaged to arrive at unisex pricing. This step is necessary since employer-sponsored plans are legally prohibited from discriminating on gender with respect to payouts.

The assessment considers not only different approaches to annuitization, but also the percentage of defined contribution wealth to be annuitized. Any annuity decision involves a tradeoff between providing higher monthly incomes and maintaining a contingency reserve in case of emergency. In addition, for a default to work it must be palatable to individuals, and entrusting one's entire life savings to an insurance company is unlikely to pass that hurdle. Thus,

\footnotetext{
${ }^{57}$ For example, Retirement Clearinghouse LLC has developed an approach designed to easily consolidate retirement savings. UTC actually encourages employees to roll over 401(k) or IRA assets from outside accounts into their UTC 401(k).

${ }^{58}$ Most workers retiring today were born between 1943 and 1954. For these workers, the full retirement age is 66. A typical worker claiming at age 64 would receive 86.66 percent of their full benefit. Delaying until age 70 would allow them to receive 132 percent of their full benefit, an increase of over 50 percent $(132 / 86.66)$.
} 
full annuitization probably does not make sense for most people. Therefore, the analysis compares the value of annuitizing 20 percent and 40 percent of defined contribution wealth to purchase a non-inflation-adjusted immediate annuity or to use these same shares to purchase an additional Social Security annuity.

In the case of deferred annuities, only the 20-percent option is relevant, because any annuity in excess of 25 percent of assets (up to $\$ 125,000$ ) would not be considered a qualifying longevity contract as specified in Treasury regulations. The 40-percent alternative would not only not qualify, but would also allocate too much of defined contribution balances to the relatively short period of expected life after age 85 and would clearly be worse than no annuitization. Even the 20-percent assumption is slightly higher than Horneff, Maurer, and Mitchell (2018) findings that typical individuals with meaningful defined contribution balances should allocate around 15 percent of their assets to a deferred annuity starting at age $85 .^{59}$

\section{Drawdown of Non-annuitized Wealth}

A key assumption in the analysis is how households draw down their non-annuitized defined contribution wealth. The assumption throughout is that households follow rules-ofthumb for drawdown, rather than optimizing their consumption through the lens of a lifecycle model. The rationale for this approach is that it is more realistic for those who would be affected by the proposed defaults.

In the case of immediate annuities and the Social Security option, households are assumed to take out their RMD each year. ${ }^{60}$ The rationale is that the RMD is the legal requirement with harsh penalties for failure to comply, and providers often offer reminders or even automatic distributions calculated to accord with the RMD. ${ }^{61}$ Although taxpayers are not required to take their RMD before age 701/2, and currently households at younger ages do not seem to be drawing down their DC assets (Poterba, Venti, and Wise 2011), this pattern likely

\footnotetext{
${ }^{59}$ In the Horneff, Maurer, and Mitchell study, 15 percent was optimal for college-educated men and women. Those with a high school education may find it optimal to annuitize only around 10 percent of defined contribution assets, while those with less than high school should allocate only about 5-9 percent to a deferred annuity. However, those with less than high school are not a focus of this paper, since they are unlikely to have substantial defined contribution balances at all.

${ }^{60} \mathrm{~A}$ recent paper finds that many households are constrained by the RMD, and would withdraw less in the absence of the requirement (Mortenson, Schramm, and Whitten 2019).

${ }^{61}$ Interestingly, Sun and Webb (2012) demonstrate that the RMD withdrawal strategy, while less than optimal, compares favorably to traditional rules of thumb such as the 4-percent rule advocated by some financial planners.
} 
reflects the fact that many of the households studied in the past still received income from defined benefit plans. As these plans gradually disappear, the assumption is that younger retirees will be forced to tap their 401(k)s earlier, and following the RMD for such withdrawals is a plausible option.

Importantly, however, the RMD drawdown approach for the non-annuitized portion of 401(k) assets does not work well with the ALDA. RMDs result in relatively low withdrawals in the early years and leave households with substantial balances at 85 when the delayed annuity kicks in. This sub-optimal pattern means that the deferred annuity would consistently be worse than no annuitization. In contrast, the advertised advantage of the ALDA is that households could consume their entire non-annuitized wealth between ages 65 and 85, when the guaranteed annuity payments begin. Therefore, the analysis considers this approach as well. ${ }^{62}$ However, households cannot both spend their entire wealth and also have liquidity for emergencies, so such an approach raises issues of adequate liquidity.

\section{Household Characteristics}

The analysis is performed on stylized households. Data on these households come from the 2016 Health and Retirement Study (HRS), a panel survey of households in which the head is age 51 or older. This survey has been administered every two years since 1992. It collects indepth information on income, work histories, assets, pensions, health insurance, disability, physical health and functioning, cognitive function, and health care expenditures. The 2016 HRS, the latest available, has 1,268 households aged 65.63 Table 2 summarizes the median defined contribution wealth and annual Social Security benefit for these households. ${ }^{64}$

\footnotetext{
${ }^{62}$ In this strategy, the household will withdraw a fixed real amount from the 80 percent of balances remaining after buying the deferred annuity. This amount will be such that if returns match their mean in every year, assets will be exhausted exactly at 85 .

${ }^{63}$ The households in the samples are ages 64-66 at the beginning of the 2016 HRS survey. The age for couples is defined as that of the household financial respondent.

${ }^{64}$ For simplicity, the analysis assumes that households do not tap their housing wealth. A reviewer pointed out that the numbers in Table 2 are different from those in Addoum (2017); the reasons are that the current analysis references different years than that paper; considers only DC wealth rather than all financial wealth; and, most importantly, uses medians rather than means.
} 
Table 2. Median Defined Contribution Wealth and Annual Social Security Benefits for Households Age 65 in 2016, By Household Type

\begin{tabular}{lcc}
\hline Household type & $\begin{array}{c}\text { Defined contribution } \\
\text { wealth }\end{array}$ & $\begin{array}{c}\text { Annual Social } \\
\text { Security benefit }^{2}\end{array}$ \\
\hline Single men & $\$ 106,000$ & $\$ 15,348$ \\
Single women & 110,000 & 14,514 \\
Married couple & 275,000 & 28,569 \\
\hline
\end{tabular}

${ }^{1}$ For households with defined contribution wealth.

${ }^{2}$ Assumes claiming at age 65.

Sources: University of Michigan, Health and Retirement Study (HRS) (2016); and authors' calculations.

These stylized households are assumed to claim their Social Security benefits at age 65, in the absence of the Social Security bridge option. Although the median claiming age is between 64 and 65 for the general population, this analysis focuses on households with at least median 401(k) wealth who tend to claim later. Under the bridge option, households receive their PIA (calculated for a full retirement age of 66) for as many years as their balances will permit and are assumed to claim once their balances are exhausted or at age 70 , whichever is later. ${ }^{65}$

\section{Mortality, Market Returns, and Consumption Shocks}

Converting wealth into future income involves three sources of uncertainty: mortality, market risk, and consumption shocks (e.g., health expenditures). ${ }^{66}$ In the base analysis, returns are assumed to equal their mean and consumption shocks are suppressed, so mortality is the only source of risk. Survival probabilities are drawn from the cohort life tables used for the 2019 Social Security Trustees Report and applied to the cohort who are age 65 in $2019 .{ }^{67}$

The second analysis introduces market risk and consumption shocks. Stochastic market returns are incorporated using Monte Carlo simulations. Households are assumed to allocate

\footnotetext{
65 The analysis uses self-reported benefits from the HRS, adjusted for any reductions from early claiming, to determine what benefits would be if the benefits were claimed at age 65. The average adjusted benefit for men and women is around $\$ 15,000$, which is consistent with the actuarial notes from the Social Security Administration's Office of the Chief Actuary. See U.S. Social Security Administration (2019a) for details.

${ }^{66}$ Inflation risk is also worth considering over the long term. The analysis considered stochastic inflation calibrated to the distribution of annual inflation rates between 2000 and 2018. However, given the small variance of inflation over this period, the resulting changes in the analysis were negligible and thus those results are not presented. For example, a shift from a world of constant average inflation to one with constant inflation at the $90^{\text {th }}$ percentile of inflation over the reference period would reduce annual consumption under a nominal annuity by about 1 percent at age 85 .

${ }^{67}$ These life tables are available from the Social Security's Office of the Chief Actuary.
} 
assets between risky equities and risk-free bonds similar to a target date fund appropriate for their age. ${ }^{68}$ The simulations conduct random draws from a log normal distribution of equity real returns, where the distribution parameters match the historical mean and variance. ${ }^{69}$ Of course, many observers believe equity returns will be lower in the future than in the past. ${ }^{70}$ Therefore, the analysis adjusts real equity returns based on methods outlined in Burtless et al. (2016) updated with current returns data. ${ }^{71}$ Based on these methods, the simulations anchor the average of 1,000 equity returns to equal 4.5 percent, in real terms. ${ }^{72}$ For simplicity, this project assumes a fixed real return from long-term bonds of 1 percent. ${ }^{73}$ Finally, inflation is assumed to be 2 percent following the Federal Reserve target. ${ }^{74}$

Consumption shocks, for the purpose of this analysis, consist of health and long-term care expenditures. ${ }^{75}$ These shocks are calibrated to HRS out-of-pocket health expenditures. To capture the fact that such expenditures tend to rise with age (e.g., see Jones et al. 2018), the

${ }^{68}$ This project follows the glide path from a typical Vanguard TDF, i.e., 50 percent in risky assets from age 65 down to 30 percent after 7 years, and constant thereafter.

${ }^{69}$ The historical data for equity returns are from the Ibbotson Large Cap Index and Wilshire 5000, updated to 2018. See Burtless et al. (2016) for more detail.

${ }^{70}$ Many industry and academic experts believe future equity returns will be lower than historical returns, mainly due to a decline in the risk-free rate. For industry examples of future expected returns, see BlackRock (2019) and Bogle and Nolan (2015). For an academic discussion of why the risk-free rate may be lower going forward, see Summers $(2014,2015)$. Summers suggest six factors. First, the market may have experienced a reduction in demand for capital due to a lower capital intensity of modern firms (e.g., WhatsApp has a greater valuation than Sony with virtually no capital required to generate that value). Second, declining population growth leads to lower interest rates as the growth of the labor force slows. Third, increasing inequality in income and an increasing capital share of income would both increase the propensity to save. Fourth, a decline in the price of capital goods would depress interest rates. Fifth, lower inflation serves to lower the after-tax real return on capital. Finally, globally an increasing share of assets is invested in safe assets such as Treasury bonds, lowering average returns.

${ }^{71}$ Burtless et al. (2016) examines three approaches to determine what future equity returns might be. The first is to look at the inverse of the price/earnings (P/E) ratio. This ratio was 19.4 as of December 2018, which suggests a real return of 5.2 percent. Short-term earnings yields, however, can be misleading. Campbell and Shiller (1998) argue that the 10-year earnings yield is a much better predictor of the returns on stocks. The current cyclically adjusted PE (CAPE) ratio is 28.3, suggesting future long-run real returns of 3.5 percent (Shiller 2019). The third approach is based on the Gordon growth model, which establishes a steady state relationship between market value, stock returns, and GDP. Assuming a dividend yield of roughly 2.1 percent (Shiller 2019) and a projected GDP growth of 2.2 percent (Social Security Administration 2019b), the stock return implied by the Gordon equation is 4.3 percent. The results of these three simple exercises suggest future real equity returns ranging from 3.5 percent to 5.2 percent. Therefore, this project anchors the average simulated equity returns to 4.5 percent, the middle of this range.

${ }^{72}$ Interestingly, this result lines up with the latest market forecast by State Street (2019), which is a real return of 4.5 percent for large-cap U.S. equities.

${ }^{73}$ This assumption is consistent with most recent academic research and projections from the industry. For example, see Horneff, Maurer, and Mitchell (2018) and Morningstar (2018).

${ }^{74}$ Allowing for uncertainty in realized inflation will generally make the Social Security annuity more attractive than other options, since it provides insurance against such uncertainty while the other annuity options examined do not.

${ }^{75}$ Following similar analysis in the literature (i.e., Horneff, Maurer, and Mitchell 2018), these consumption shocks do not directly provide utility and can be thought of as income shocks. 
shocks occur with a 10-percent probability at every age with a magnitude corresponding to the $90^{\text {th }}$ percentile of expenditures at that age. ${ }^{76}$ These expenses are assumed to be covered by remaining account balances, if sufficient, then by funds set aside for Social Security deferral, and finally, if all liquid assets are exhausted, by payments out of current income. In other words, households will not have their "typical" consumption impacted by these shocks unless they have exhausted their assets. Furthermore, households who exhaust their assets are assumed to have a consumption floor of $\$ 10,000$ per year, corresponding roughly to the income which would allow them to meet the Medicaid eligibility criteria. ${ }^{77}$

\section{Calculating Utility Equivalent Wealth}

To calculate utility equivalent wealth - the amount of wealth required to achieve the same utility - it is assumed that, for each age starting from 65 , each stylized household immediately consumes its Social Security income, annuity income, and withdrawals. That is, households do not save in retirement. Utility is then assigned each year at the household level by assuming a standard Constant Relative Risk Aversion (CRRA) utility function with a risk aversion parameter of $\gamma=2$, weighted by the probability of being in certain states, and discounted to age 65 by a time preference parameter of $\beta=0.96 .^{78}$ The expected present value of lifetime utility (EPVU) is represented in the equation below:

\footnotetext{
${ }^{76}$ In particular, the $90^{\text {th }}$ percentile of out-of-pocket health expenditures is estimated by 5 -year age bins, starting at age 65 .

${ }^{77}$ See Centers for Medicare \& Medicaid Services (2019). For an individual over age 65 in 2019, eligibility for Medicaid begins at $\$ 1,061$ per month. Individuals above the Federal Poverty Line may also face cost sharing of 10 percent of costs (see Kaiser Family Foundation 2017); consequently, they will retain roughly $\$ 10,000$ per year. ${ }^{78}$ The choice of risk aversion parameter and discount rate follows standard literature (e.g., Horneff, Maurer, and Mitchell 2018). Estimates of risk aversion in the literature have a wide range, with Chetty (2006) finding values around 1, while Barsky et al. (1997), for example, estimate values around 4. Intuitively, a larger $\gamma$ will lead to greater valuations for options yielding smooth consumption, such as the immediate annuity and the Social Security deferral. Reducing $\beta$ would lead to greater valuation of options frontloading consumption. In particular, the ALDA with accelerated drawdown so assets are exhausted at 85 would appear more attractive.
} 


$$
\begin{aligned}
& \operatorname{EPVU}_{65}=\sum_{t=65}^{120} \beta^{(t-65)}\left(P_{t}^{m} \omega^{m} \frac{\left(\text { SSB }_{t}^{m}+\text { Annuity }_{t}+\text { Withdraw }_{t}\right)^{1-\gamma}-1}{1-\gamma}\right. \\
& +P_{t}^{f} \omega^{f} \frac{\left(\text { SSB }_{t}^{w}+\text { Annuity }_{t}+\text { Withdraw }_{t}\right)^{1-\gamma}-1}{1-\gamma} \\
& +P_{t}^{\text {both }}\left(\omega^{m} \frac{\left(\eta\left(S S B_{t}^{m}+0.5 \text { Annuity }_{t}+0.5 \text { Withdraw }_{t}\right)\right)^{1-\gamma}-1}{1-\gamma}\right. \\
& \left.\left.+\omega^{f} \frac{\left(\eta\left(S S B_{t}^{w}+0.5 \text { Annuity }_{t}+0.5 \text { Withdraw }_{t}\right)\right)^{1-\gamma}-1}{1-\gamma}\right)\right)
\end{aligned}
$$

where $S S B_{t}^{m}$ and $S S B_{t}^{w}$ represent the Social Security benefits for men and women, respectively; Annuity $_{t}$ represents annuity income, if any; Withdraw $_{t}$ represents any additional withdrawals required to satisfy RMD rules; $\omega^{m}$ and $\omega^{f}$ are Pareto weights for men and women; and $\eta$ is the equivalence scale of consumption for couples. ${ }^{79}$ For households starting the simulation at age 65 with both a husband and a wife living, the following states are allowed: only the husband survives; only the wife survives; or both survive. The probabilities for each of these states are $P_{t}^{m}, P_{t}^{f}$, and $P_{t}^{b o t h}$, respectively. In this way, each strategy for a stylized household is associated with an EPVU.

For married households, each spouse is assumed to derive utility from his or her own consumption, but not from the consumption of the other spouse. Furthermore, each spouse is assumed to have equal Pareto weights $\left(\omega^{m}=\omega^{f}=0.5\right)$, and these weights are not adjusted upon the death of a spouse.$^{80}$ Finally, an equivalence scale is applied to household consumption so that every dollar is worth 1.52 dollars of consumption for a two-person household (due to economies of scale). ${ }^{81}$

Once the EPVU is calculated for the benchmark case - no annuitization - the process is repeated for each of the five other annuitization strategies. At first, the same initial defined contribution wealth is assumed and, if the EPVU is higher (lower) than the benchmark case, an iterative process begins whereby defined contribution wealth is decreased (increased) until the EPVU in the alternative is equal to the benchmark. This decrease or increase in wealth required

\footnotetext{
${ }^{79}$ With respect to withdrawals, the alternative drawdown strategy assumed for the deferred annuity does not follow the RMD rules.

${ }^{80}$ This assumption is consistent, for example, with Fadlon and Nielsen (2019) who maintain an equal weight for the individual's utility irrespective of the current composition of the household.

${ }^{81}$ See Browning, Chiappori, and Lewbel (2013).
} 
to make different strategies equivalent in terms of well-being measures how much better or worse the alternative is compared to the benchmark. This process is repeated in each of the 1,000 simulated series of market returns and the results are averaged. ${ }^{82}$

\section{Results}

Three sets of results are presented below. The base case shows, for the median male, female, and couple household the relative ranking of the annuitization options when mortality is the only source of uncertainty. The second adds stochastic returns and consumption shocks to the analysis. And, the third looks at households at the $75^{\text {th }}$ and $90^{\text {th }}$ percentile in the wealth distribution.

Base Case. The results of this exercise, which are presented in Table 3, are generally intuitive. For each household type, purchasing an immediate annuity produces a better outcome than no annuitization, and annuitizing 40 percent is better than annuitizing 20 percent. This finding is consistent with the literature, which shows full annuitization is optimal assuming no value for bequests or precautionary saving in retirement. Couples gain less from any form of annuitization than singles because of their ability to self-insure described earlier. ${ }^{83}$

As expected, annuitizing a portion of wealth to defer Social Security claiming is preferred to purchasing an immediate annuity due to the advantageous features of Social Security discussed above. As in the case of an immediate annuity, annuitizing a larger share of wealth requires less initial wealth to achieve the same level of utility.

\footnotetext{
${ }^{82}$ This project runs simulations 1,000 times to satisfy the minimum requirement for a 90 -percent confidence interval. See Byrne (2013).

83 The ordering of options for couples is quite similar to that for single-person households, with one exception. Allocating 40 percent of assets to the Social Security bridge does not yield a large improvement relative to allocating 20 percent, and, in fact, performs worse than the deferred annuity. The reason for this poor performance is that the Social Security bridge payment - the PIA - differs from the actual benefit. This discrepancy does not make a big difference if people defer for only a year or two, but matters a lot if they defer for several years. For single-person households of median wealth, their assets allow a delay in claiming of just a year or two, so their benefit is, in practice, not very different from their PIA. However, for couples devoting 40 of assets to the Social Security bridge allows for four years of deferral, resulting in a substantial jump in income upon claiming. An alternative approach would be to set the Social Security bridge payment at the worker's projected benefit. Analysis not shown here verifies that couples do, in fact, benefit from 40-percent allocation to deferred claiming with such a "smooth" payment schedule. Such a policy, however, would be complicated in practice, so the focus here is setting distributions to the PIA.
} 
Table 3. Wealth Required to Achieve the Same Level of Utility for Single and Married Households of Median Wealth, by Strategy

\begin{tabular}{lccccc}
\hline & $\begin{array}{c}\text { Share of } \\
\text { wealth used }\end{array}$ & & \multicolumn{2}{c}{ Equivalent wealth relative to no annuitization } \\
\cline { 4 - 6 } \cline { 5 - 6 } Option & $0 \%$ & & 1.00 & Single men & Single women Married couples \\
\cline { 1 - 4 } No annuitization & 20 & & 0.90 & 1.00 & 1.00 \\
1. Immediate annuity & 40 & & 0.80 & 0.91 & 0.95 \\
2. Immediate annuity & 20 & & 0.80 & 0.81 & 0.89 \\
3. Deferring Social Security & 40 & & 0.71 & 0.80 & 0.89 \\
4. Deferring Social Security & 20 & & 1.10 & 0.72 & 0.89 \\
5a. Deferred annuity (RMD) & 20 & & 0.72 & 0.74 & 1.10 \\
5b. Deferred annuity & & & & 0.84 \\
\hline
\end{tabular}

Source: Authors' calculations.

The results for the deferred annuity are mixed. On the one hand, as discussed, the option that involves the drawdown based on the RMD (5a) produces a worse outcome than no annuitization, reflecting the fact that households withdraw sub-optimal amounts between ages 65 and 85. On the other hand, the option that assumes households withdraw all their assets over the period 65-85 (5b) produces a much better outcome.

Taken at face value, the results suggest that investing 20 percent of accumulated assets in an ALDA and spending all non-annuitized assets between ages 65 and 85 produces nearly the same level of well-being as using 40 percent of defined contribution assets to increase the Social Security annuity and drawing down non-annuitized assets according to the RMD. The ALDA approach requires less resources and involves a product that already exists, while the Social Security bridge option requires more resources and establishing a new arrangement. The problem with the existing comparison, however, is that it focuses only on the income side of the equation and ignores liquidity. Figure 3 shows that the deferred annuity option leaves the household with little liquidity in case of consumption shocks particularly near or past age 85 . Similarly, though less starkly, the immediate annuity options leave households with less liquidity at early ages than allocating an equivalent share of assets to deferring Social Security. The next step is to include consumption shocks and stochastic returns in the model. 
Figure 3. Defined Contribution Wealth Balances over Remaining Lifespan by Strategy, in Real Dollars

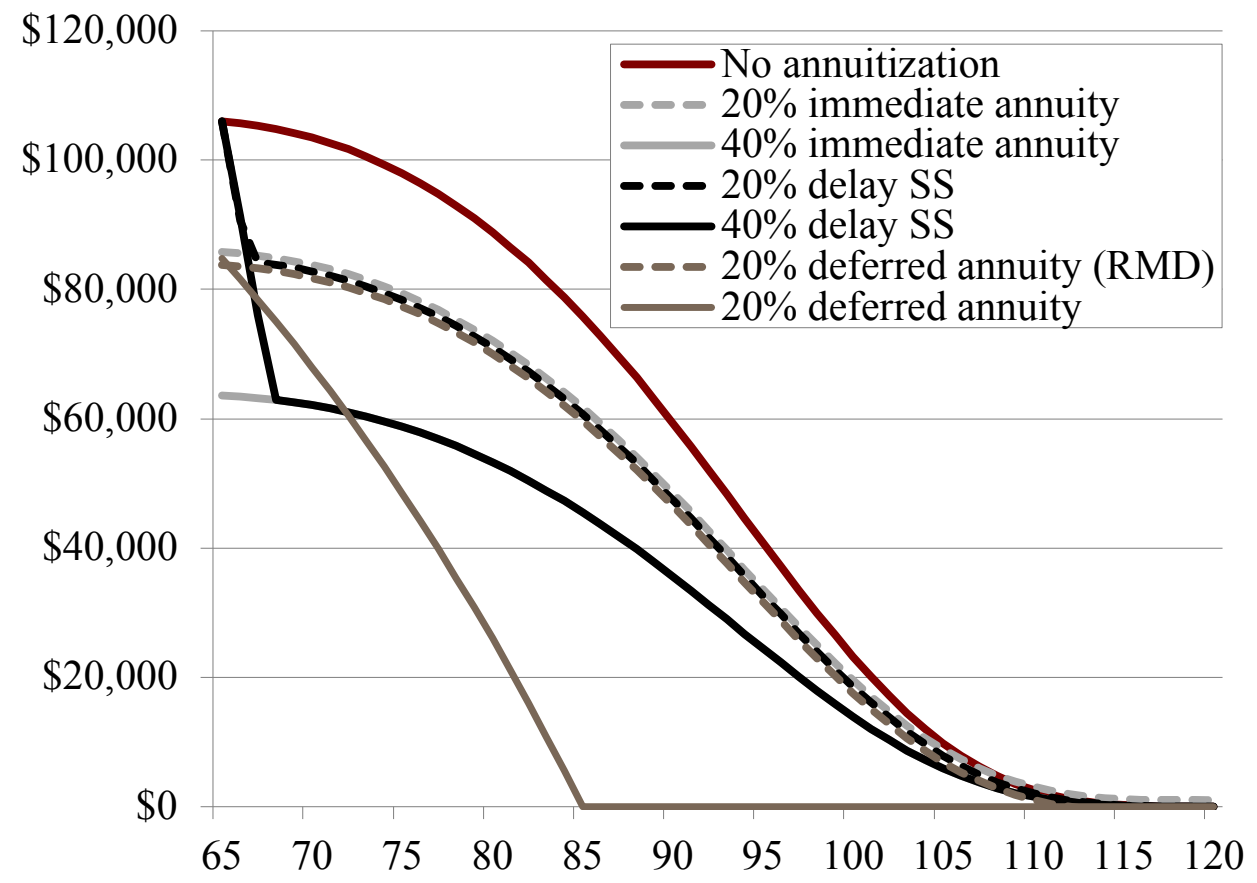

Source: Authors' calculations.

With Consumption Shocks and Stochastic Returns. Introducing shocks both makes annuitization less attractive generally because of the need for liquidity and changes the ranking of the Social Security bridge relative to the deferred annuity (see Table 4). The changes are almost entirely due to the shocks; stochastic returns have little impact. In the remainder of the analysis, only single-person households will be considered due to the computational complexity of analyzing couples. 
Table 4. Wealth Required to Achieve the Same Level of Utility for Single Households of Median Wealth in the Presence of Stochastic Returns and Consumption Shocks, by Strategy

\begin{tabular}{lcccc}
\hline & $\begin{array}{c}\text { Share of } \\
\text { wealth used }\end{array}$ & & \multicolumn{2}{c}{ Equivalent wealth relative to no annuitization } \\
\cline { 4 - 5 } Option & $0 \%$ & & Single men & Single women \\
\hline No annuitization & 20 & & 0.00 & 1.00 \\
1. Immediate annuity & 40 & 0.84 & 0.92 \\
2. Immediate annuity & 20 & 0.82 & 0.85 \\
3. Deferring Social Security & 40 & 0.76 & 0.82 \\
4. Deferring Social Security & 20 & 1.09 & 0.76 \\
5a. Deferred annuity (RMD) & 20 & 0.86 & 1.06 \\
5b. Deferred annuity & & & 0.86 \\
\hline
\end{tabular}

Source: Authors' calculations.

The deferral of Social Security is the clear winner once shocks are incorporated into the model. Furthermore, more deferral is better than less deferral, with the 40-percent option leading the 20-percent option. For the deferred annuity, what was an advantage in the deterministic scenario - large consumption in early years - becomes a liability when households are left with no asset buffer at age 85 (and small buffers in the years leading up to 85). The question is whether these rankings hold at different points in the wealth distribution.

HOUSEHOLDS AT THE 75TH AND 90TH PERCENTILE: Table 5 shows the results for households at the $75^{\text {th }}$ percentile of wealth (roughly $\$ 250,000$ for a single-person household). At such wealth levels, 20 percent of assets is sufficient to delay claiming almost to age 70, exhausting the Social Security deferral option. Therefore, Table 5 does not consider using 40 percent of wealth to delay claiming, and correspondingly does not consider devoting 40 percent of wealth to an immediate annuity, either. ${ }^{84}$

For these relatively higher-wealth households, the deferred annuity strategy is again competitive, edging out the Social Security bridge option, as the income derived from this annuity after age 85 provides enough of a buffer so that even if a health shock hits consumption does not fall to very low levels. Nevertheless, if following the RMD remains a plausible rule of thumb for retirees, the deferred annuity remains a very poor choice, for both median and $75^{\text {th }}$ percentile wealth households.

\footnotetext{
${ }^{84}$ Furthermore, for households of above-median wealth the eventual claiming age substantially surpasses the FRA, leading to a discontinuous jump in income upon claiming. Analysis not shown here confirms that if the default Social Security bridge targets the expected benefit, rather than the PIA, the Social Security options look even more attractive than they do under the simpler policy targeting the PIA.
} 
Table 5. Wealth Required to Achieve the Same Level of Utility for Single Households of $75^{\text {th }}$ Percentile Wealth in the Presence of Stochastic Returns and Consumption Shocks, by Strategy

\begin{tabular}{lcccc}
\hline & $\begin{array}{c}\text { Share of } \\
\text { wealth used }\end{array}$ & & Equivalent wealth relative to no annuitization \\
\cline { 4 - 5 } Option & $0 \%$ & & Single men & Single women \\
\hline No annuitization & 20 & & 1.00 & 1.00 \\
1. Immediate annuity & 20 & & 0.91 & 0.92 \\
3. Deferring Social Security & 20 & & 1.11 & 0.89 \\
5a. Deferred annuity (RMD) & 20 & & 0.85 & 1.08 \\
5b. Deferred annuity & 20 &
\end{tabular}

Source: Authors' calculations.

The story is somewhat different for households at the $90^{\text {th }}$ percentile of wealth (about $\$ 500,000$ to $\$ 600,000$ for a single-person household), because they need only about 10 percent of their wealth to delay claiming to age 70 . Therefore, two strategies are considered: 1) allocating 10 percent to each option; and 2) allocating 20 percent by augmenting the 10 percent to the Social Security bridge with 10 percent to immediate or deferred annuities (see Table 6).

Table 6. Wealth Required to Achieve the Same Level of Utility for Single Households of $90^{\text {th }}$ Percentile Wealth in the Presence of Stochastic Returns and Consumption Shocks, by Strategy

\begin{tabular}{lccc}
\hline & Share of & \multicolumn{2}{c}{ Equivalent wealth relative to no annuitization } \\
\cline { 3 - 4 } Option & $0 \%$ & Single men & Single women \\
\hline No annuitization & 1.00 & 1.00 \\
Allocating & 10 & percent of wealth & \\
Immediate annuity & 10 & 0.95 & 0.95 \\
Deferring Social Security & 10 & 0.94 & 0.95 \\
Deferred annuity & 10 & 0.84 & 0.88 \\
& Allocating & 20 & percent of wealth \\
Immediate annuity & 20 & 0.91 & 0.91 \\
$\begin{array}{l}\text { Deferring Social Security }+ \\
\text { deferred annuity }\end{array}$ & $10+10$ & 0.79 & 0.83 \\
$\begin{array}{l}\text { Deferring Social Security }+ \\
\text { immediate annuity }\end{array}$ & $10+10$ & 0.89 & 0.90 \\
\hline
\end{tabular}

Source: Authors' calculations.

When allocating 10 percent of assets, both the immediate annuity and the Social Security bridge represent only a mild improvement relative to no annuitization. These modest gains reflect the fact that annuitizing only 10 percent of assets is very similar to not annuitizing at all. 
In contrast, buying a deferred annuity leaves households somewhat better off, because the income stream purchased for 10 percent of relatively large starting assets is sufficient to cover shocks even after age 85 .

To get to higher levels of annuitization requires a hybrid strategy: allocating 10 percent to Social Security deferral and then allocating an additional 10 percent to either a deferred or an immediate annuity. The hybrid options perform well relative to the other strategies, particularly when the Social Security bridge is combined with a deferred annuity. These results suggest that while the Social Security bridge option works well for many 401(k) participants, it alone would lead to too little annuitization for wealthy households. ${ }^{85}$ This shortfall, however, could be easily filled by having deferred annuities easily available within the plan.

\section{Conclusion}

As the first cohort entirely dependent on 401(k) plans starts to retire, the question of how they will manage their accumulated assets over their retirement takes on increased urgency. Without some help, retirees risk spending too quickly and exhausting their resources or too slowly and depriving themselves of necessities. They must also worry about how to invest their assets in retirement.

Fortunately, strategies are available that would ensure individuals a higher level of lifetime income, reduce the likelihood that they will outlive their resources, and alleviate some of the anxiety associated with post-retirement investing. Workers could use a portion of their 401(k) and IRA assets to purchase an immediate annuity, purchase an advanced life deferred annuity, or defer claiming Social Security. And workers would be more likely to use these options if they were embedded in a $401(\mathrm{k})$ plan - particularly as the default.

In order to compare the desirability of these three approaches, it is necessary to sketch out the Social Security bridge option. The proposal considered here would introduce a default into 401(k) plans that would use 401(k) assets to pay retiring individuals ages 60-69 an amount equal to their Social Security Primary Insurance Amount (PIA) - the monthly amount at an individual's full retirement age. Providing a temporary stream of income to replace an

\footnotetext{
${ }^{85}$ This mirrors results from recent work showing that setting a mandatory annuitization rate can lead some individuals to interpret the mandatory amount as recommended or sufficient (Hurwitz, Sade, and Winter 2019). Such individuals might have annuitized more than the mandated amount in the absence of the mandate, and thus the mandate can actually reduce the share of assets that is annuitized.
} 
individual's Social Security benefit would break the link between retiring and claiming. As a result, retirees could delay claiming Social Security in order to maximize this valuable source of annuity income.

The assessment considers not only different approaches to annuitization, but also the percentage of defined contribution wealth to be annuitized. For a default to work, it must be palatable to individuals, and entrusting one's entire life savings to an insurance company is unlikely to pass that hurdle. Since full annuitization probably does not make sense for most people, the analysis compares the value of annuitizing 20 percent and 40 percent of defined contribution wealth.

The results show that, once shocks are incorporated into the model, the Social Security bridge option provides the best outcome for households in the middle of the wealth distribution. In addition to using the bridge option, households at the $90^{\text {th }}$ percentile of wealth would also benefit from further annuitization, such as easy access to a deferred annuity.

Of course, this research is not the final word on the best approach for using 401(k) wealth to generate lifetime income. While this study shows clear advantages for the Social Security bridge default in a few stylized settings, the research could be expanded - both through enhancements to the model and experiments to test how real people would respond to different approaches.

In terms of the model, the simplest extensions would be varying the assumed age for claiming in the absence of the Social Security bridge default and expanding household utility to allow for bequest motives. An alternative approach would be to evaluate optimized drawdown strategies - instead of using the RMD - to estimate the optimal share of wealth to be devoted to each product.

On the empirical side, lab or field experiments could be used to find what share of households would stick with the default, whether the Social Security bridge successfully breaks the link between retirement and claiming, and whether it could have unintended consequences such as encouraging some households to retire earlier. The answers to these questions would be invaluable to designing a drawdown strategy that would help ensure a more secure retirement for those about to retire dependent on their $401(\mathrm{k})$. 


\section{References}

Addoum, Jawad M. 2017. "Household Portfolio Choice and Retirement." Review of Economics and Statistics 99(5): 870-883.

Agnew, Julie R., Lisa R. Anderson, Jeffrey R. Gerlach, and Lisa R. Szykman. 2008. "Who Chooses Annuities? An Experimental Investigation of the Role of Gender, Framing, and Defaults." American Economic Review 98(2): 418-22.

Ameriks, John. 2002. "Recent Trends in the Selection of Retirement Income Streams among TIAA-CREF Participants." Issue No.74. New York, NY: TIAA-CREF Institute.

Ameriks, John, Andrew Caplin, Steven Laufer, and Stijn Van Nieuwerburgh. 2011. "The Joy of Giving or Assisted Living? Using Strategic Surveys to Separate Public Care Aversion from Bequest Motives.” The Journal of Finance 66(2): 519-561.

Barsky, Robert B., F. Thomas Juster, Miles S. Kimball, and Matthew D. Shapiro. 1997. "Preference Parameters and Behavioral Heterogeneity: An Experimental Approach in the Health and Retirement Study." Quarterly Journal of Economics 112(2): 537-579.

Benartzi, Shlomo, Alessandro Previtero, and Richard H. Thaler. 2011. "Annuitization Puzzles." Journal of Economic Perspectives 25(4): 143-164.

Benitez-Silva, Hugo. 2003. "The Annuity Puzzle Revisited." Working Paper No. WP 2003-055. Ann Arbor, MI: University of Michigan Retirement Research Center.

Bernheim, B. Douglas. 1991. "How Strong are Bequest Motives? Evidence Based on Estimates of the Demand for Life Insurance and Annuities." Journal of Political Economy 99(5): 899-927.

BlackRock Institutions. 2019. “Asset Class Return and Volatility Expectations.” Available at: https://www.blackrock.com/institutions/en-us/insights/charts/capital-market-assumptions

Bogle, John C. and Michael W. Nolan. 2015. “Occam's Razor Redux: Establishing Reasonable Expectations for Financial Market Returns." The Journal of Portfolio Management 42(1): 119-134.

Brown, Jason and Mark Warshawsky. 2013. "The Life Care Annuity: A New Empirical Examination of an Insurance Innovation that Addresses Problems in the Markets for Life Annuities and Long-Term Care Insurance." Journal of Risk and Insurance 80(3): 677 703.

Brown, Jeffrey R. 1999. “Are the Elderly Really Over-annuitized? New Evidence on Life Insurance and Bequests." Working Paper 7193. Cambridge, MA: National Bureau of Economic Research. 
Brown, Jeffrey R. 2009. "Understanding the Role of Annuities in Retirement Planning." In Overcoming the Savings Slump: How to Increase the Effectiveness of Financial Education and Saving Programs, edited by Annamaria Lusardi. Chicago, IL: University of Chicago Press.

Brown, Jeffrey R. and Amy Finkelstein. 2011. "Insuring Long-Term Care in the United States." Journal of Economic Perspectives 25(4): 119-142.

Brown, Jeffrey R. and James M. Poterba. 2000. "Joint Life Annuities and Annuity Demand by Married Couples.” Journal of Risk and Insurance 67(4): 527-556.

Brown, Jeffrey R. and Mark J. Warshawsky. 2004. "Longevity-Insured Retirement Distributions from Pension Plans: Market and Regulatory Issues.” Working Paper 8064. Cambridge, MA: National Bureau of Economic Research.

Brown, Jeffrey R., Arie Kapteyn, Erzo Luttmer, and Olivia S. Mitchell. 2017. "Cognitive Constraints on Valuing Annuities." Journal of the European Economic Association 15(2): 429-462.

Brown, Jeffrey R., Jeffrey R. Kling, Sendhil Mullainathan, and Marian V. Wrobel. 2008. "Why Don't People Insure Late-Life Consumption? A Framing Explanation of the UnderAnnuitization Puzzle.” American Economic Review 98(2): 304-309.

Brown, Jeffrey R., Olivia S. Mitchell, and James M. Poterba. 2001. "The Role of Real Annuities and Indexed Bonds in an Individual Accounts Retirement Program." In Risk Aspects of Investment-based Social Security Reform, edited by John V. Campbell and Martin S. Feldstein, 321-370. Chicago, IL: University of Chicago Press.

Brown, Jeffrey R., Olivia S. Mitchell, and James M. Poterba. 2002. "Mortality Risk, Inflation Risk, and Annuity Products.” In Innovations in Retirement Financing, eds. Olivia Mitchell, Zvi Bodie, Brett Hammond, and Stephen Zeldes, 175-197. Philadelphia, PA: University of Pennsylvania Press.

Brown, Jeffrey R., Olivia S. Mitchell, James M. Poterba, and Mark J. Warshawsky. 2001. The Role of Annuity Markets in Financing Retirement. Cambridge, MA: The Massachusetts Institute of Technology Press.

Browning, Martin, Pierre-Andre Chiappori, and Arthur Lewbel. "Estimating Consumption Economies of Scale, Adult Equivalence Scales, and Household Bargaining Power." Review of Economic Studies 80: 1267-1303.

Burtless, Gary, Anqi Chen, Wenliang Hou, and Alicia H. Munnell. 2016. "How Would Investing in Equities Have Affected the Social Security Trust Fund?” Working Paper 2016-6. Chestnut Hill, MA: Center for Retirement Research at Boston College. 
Bütler, Monika and Federica Teppa. 2007. "The Choice between an Annuity and a Lump Sum: Results from Swiss Pension Funds." Journal of Public Economics 91(10): 1944-1966

Byrne, Barbara M. 2013. Structural Equation Modeling with Mplus: Basic Concepts, Applications, and Programming. New York, New York: Routledge Publishing.

Campbell, John Y. and Robert J. Shiller. 1998. "The Dividend-price Ratio and Expectations of Future Dividends and Discount Factors." The Review of Financial Studies 1(3): 195-228.

Centers for Medicare \& Medicaid Services. 2019. "Seniors \& Medicare and Medicaid Enrollees." Baltimore, MD.

Centers for Medicare \& Medicaid Services. 2017. National Health Expenditure Accounts. Baltimore, MD.

Chetty, Raj. 2006. "A New Method of Estimating Risk Aversion.” American Economic Review 96(5): 1821-1834.

Davidoff, Thomas, Jeffrey R. Brown, and Peter A. Diamond. 2005. "Annuities and Individual Welfare.” American Economic Review 95(5): 1573-1590.

De Nardi, Mariacristina, Eric French, and John B. Jones. 2010. "Why Do the Elderly Save? The Role of Medical Expenses.” Journal of Political Economy 118(1): 39-75.

Fadlon, Itzik and Torben Heien Nielsen. 2019. "Household Labor Supply and the Gains from Social Insurance." Journal of Public Economics 171: 18-28.

Finkelstein, Amy and James M. Poterba. 2002. "Selection Effects in the United Kingdom Individual Annuities Market." The Economic Journal 112(476): 28-50.

Finkelstein, Amy and James M. Poterba. 2004. "Adverse Selection in Insurance Markets: Policyholder Evidence from the UK Annuity Market." Journal of Political Economy 112(1): 183-208.Gale, William G., David C. John, and Spencer Smith. 2012. "New Ways to Promote Retirement Saving." Report No. 2012-9. Washington, DC: AARP Public Policy Institute.

Freidman, Benjamin M. and Mark J. Warshawsky. 1990. "The Cost of Annuities: Implications for Saving Behavior and Bequests." Quarterly Journal of Economics 105(1): 135-154.

Gale, William, David John, and Spencer Smith. 2012. "New Ways to Promote Retirement Saving." Washington, DC: AARP Public Policy Institute.

Goodman, Benjamin and David P. Richardson. 2014. "TIAA and CREF: Program Features and Recent Evidence on Performance and Utilization." TIAA-CREF Institute Research Dialogue No. 114. New York City, NY. 
Horneff, Vanya, Raimond Maurer, and Olivia S. Mitchell. 2018. "Putting the Pension Back in 401(k) Retirement Plans: Optimal versus Default Longevity Income Annuities." Working Paper 2017-3. Philadelphia, PA: Pension Research Council.

Horneff, Vanya, Raimond Maurer, Olivia S. Mitchell, and Ralph Rogalla. 2015. "Optimal Life Cycle Portfolio Choice with Variable Annuities Offering Liquidity and Investment Downside Protection." Insurance: Mathematics and Economics 63: 91-107.

Hurd, Michael and Constantijn Panis. 2006. "The Choice to Cash Out Pension Rights at Job Change or Retirement." Journal of Public Economics 90(12): 2213-2227.

Hurwitz, Abigail, Orly Sade, and Eyal Winter. 2019. "Can Mandatory Minimum Annuity Laws Have Unintended Consequences? An Experimental Study.” Working Paper.

John, David C., William G. Gale, J. Mark Iwry, and Aaron Krupkin. 2019. "From Saving to Spending: A Proposal to Convert Retirement Account Balances into Automatic and Flexible Income.” Washington, DC: The Brookings Institution.

Johnson, Richard W., Leonard E. Burman, and Deborah I. Kobes. 2004. "Annuitized Wealth at Older Ages: Evidence from the Health and Retirement Study." Final Report to the Employee Benefits Security Administration, Department of Labor. Urban Institute, Washington, DC.

Jones, John Bailey, Mariacristina Di Nardi, Eric French, Rory McGee, and Justin Kirschner. 2018. "The Lifetime Medical Spending of Retirees.” Working Paper No. 24599. Cambridge, MA: National Bureau of Economic Research.

Kaiser Family Foundation. 2017. "Medicaid and CHIP Eligibility, Enrollment, Renewal, and Cost Sharing Policies as of January 2017: Findings from a 50-State Survey." San Francisco, CA.

Koenig, Gary, Jason J. Fichtner, and William G. Gale. 2018. "Supplemental Transition Accounts for Retirement: A Proposal to Increase Retirement Income Security and Reform Social Security." Public Policy \& Aging Report 28(1): S22-S34.

Kotlikoff, Laurence J., and Avia Spivak. 1981. "The Family as an Incomplete Annuities Market." Journal of Political Economy 89(2): 372-391.

LIMRA Secure Retirement Institute. 2019 U.S. Individual Annuities Sales Survey $1^{\text {st }}$ Quarter 2019. Table 1. Windsor, CT.

Lockwood, Lee M. 2012. "Bequest Motives and the Annuity Puzzle." Review of Economic Dynamics 15(2): 226-243.

Lockwood, Lee M. 2018. "Incidental Bequests and the Choice to Self-Insure Late-Life Risks." American Economic Review 108(9): 2513-2550. 
McCarthy, David and Olivia S. Mitchell. 2002. "Estimating International Adverse Selection in Annuities". North American Actuarial Journal (October): 38-54.

Milevsky, Moshe A. 2005. "Real Longevity Insurance with a Deductible: Introduction to Advanced-Life Delayed Annuities (ALDA)." North American Actuarial Journal 9(4): 109-122.

Milevsky, Moshe A. and Virginia R. Young. 2007. "Annuitization and Asset Allocation." Journal of Economic Dynamics and Control 31(9): 3138-3177.

Mitchell, Olivia S., James M. Poterba, Mark J. Warshawsky, and Jeffrey R. Brown. 1999. "New Evidence on the Money's Worth of Individual Annuities." American Economic Review 89(5): 1299-1318.

Modigliani, Franco. 1986. "Life Cycle, Individual Thrift, and the Wealth of Nations." American Economic Review 76(3): 297-313.

Morningstar. 2018. “Morningstar Markets Observer Q4 2018.” Report No. Q4 2018. Chicago, IL.

Mortenson, Jacob A., Heidi R. Schramm, and Andrew Whitten. 2019. "The Effects of Required Minimum Distribution Rules on Withdrawals from Traditional IRAs." National Tax Journal 72(3): 507-542.

Mottola, Gary R. and Stephen P. Utkus. 2007. "Lump Sum or Annuity? An Analysis of Choice in DB Pension Payouts.” Working Paper 30. Valley Forge, PA: Vanguard Center for Retirement Research.

Munnell, Alicia H. and Steven A. Sass. 2009. "Working Longer: The Solution to the Retirement Income Challenge.” Washington, DC: Brookings Institution Press.

Munnell, Alicia H. and Annika E. Sundén (editors). 2003. Death and Dollars: The Role of Gifts and Bequests in America. Washington, DC: Brookings Institution Press.

Multack, Megan and Claire Noel-Miller. 2014. "Who Relies on Medicare? Profile of the Medicate Population." Fact Sheet No. 298. Washington, DC: AARP Public Policy Institute.

Murphy, Philip, Steve Vernon, Kevin T. Hanney, and Kenneth Levine. 2018. "Helping Plan Participants Help Themselves: Withdrawal Strategies in a Self-Serve World.” Chicago, IL: Plan Sponsor Council of America.

National Organization of Life \& Health Insurance Guaranty Associations. 1992-2015. Herndon, VA. 
Peijnenburg, Kim, Theo Nijman, and Bas JM Werker. 2016. "The Annuity Puzzle Remains A Puzzle." Journal of Economic Dynamics and Control 70: 18-35.

Poterba, James M., Steven Venti, and David Wise. 2011. "The Composition and Drawdown of Wealth in Retirement." Journal of Economic Perspectives 25(4): 95-118.

Plan Sponsor Council of America. 2018. "60th Annual Survey of Profit Sharing and 401(k) Plans." Chicago, IL.

Reichling, Felix and Kent Smetters. 2015. "Optimal Annuitization with Stochastic Mortality and Correlated Medical Shocks.” American Economic Review 105(11): 3273-3320.

Sagara, Namika, John Payne, Suzanne Shu, Kirstin Appelt, and Eric Johnson. 2011. "Live to Or Die By: Framing Effects on Life Expectations and Life Annuity Choice." ACR North American Advances 39: 210-211.

Shiller, Robert. 2019. "Online Data". Available at: http://www.econ.yale.edu/ shiller/data.htm

Shoven, John B. and Sita Nataraj Slavov. 2014. "Does It Pay to Delay Social Security?” Journal of Pension Economics \& Finance 13(2): 121-144.

Society of Actuaries. 2017. “2017 Risks and Process of Retirement Survey.” Schaumburg, IL.

Society of Actuaries and LIMRA. 2018. "Variable Annuity Guaranteed Living Benefits Utilization: 2015 Experience.” Report.

State Street. 2019. "SSGA Long-Term Asset Class Forecasts.” Boston, MA.

Steinorth, Petra and Olivia S. Mitchell. 2015. "Valuing Variable Annuities with Guaranteed Minimum Lifetime Withdrawal Benefits." Insurance: Mathematics and Economics 64: 246-258.

Summers, Lawrence H. 2014. "U.S. Economic Prospects: Secular Stagnation, Hysteresis, and the Zero Lower Bound." Business Economics 49(2): 65-73.

Summers, Lawrence H. 2015. "Demand Side Secular Stagnation." American Economic Review: Papers and Proceedings 105(5): 60-65.

Sun, Wei and Anthony Webb. 2012. "Should Households Base Asset Decumulation Strategies on Required Minimum Distribution Tables?” Working Paper 2012-10. Chestnut Hill, MA: Center for Retirement Research at Boston College.

TIAA Institute. 2019. "Entering Our Second Century of Helping People Pursue Financial Wellbeing." New York, NY. 
Thaler, Richard H. 1994. "Some Empirical Evidence on Dynamic Inconsistency." Reprint. In Quasi-Rational Economics, edited by Richard H. Thaler, 127-136. New York, NY: Russell Sage Foundation.

University of Michigan. Health and Retirement Study 2016. Ann Arbor, MI.

U.S. Department of the Treasury. 2014a. "Treasury Issues Final Rules Regarding Longevity Annuities.” Press Release (July 1). Washington, DC.

U.S. Department of the Treasury. 2014b. "Treasury Issues Guidance to Encourage Annuities in 401(k) Plans.” Press Release (October 24). Washington, DC.

U.S. Social Security Administration. 2019a. "Replacement Rates for Hypothetical Retired Workers.” Actuarial Note No. 2019.9. Washington, DC.

U.S. Social Security Administration. 2019b. The Annual Report of the Board of Trustees of the Federal Old-Age and Survivors Insurance and Federal Disability Insurance Trust Funds. Washington, DC.

U.S. Social Security Administration 2018. Social Security Annual Statistical Supplement, Table 6.B5. Washington, DC.

Vanguard. 2019. "How America Saves 2019: Vanguard 2018 Defined Contribution Plan Data." Valley Forge, PA.

Vernon, Steve. 2018. “How to 'Pensionize’ Any IRA or 401(k) Plan.” Stanford, CA: Stanford Center on Longevity.

Wolff, Edward N. 2018. "The Decline of African-American and Hispanic Wealth since the Great Recession." Working Paper No. 25198. Cambridge, MA: National Bureau of Economic Research.

Yaari, Menahem E. 1965. "Uncertain Lifetime, Life Insurance, and the Theory of the Consumer." The Review of Economic Studies 32(2): 137-150. 